\title{
14
}

\section{Investigating the Potential for Micro-work and Online-Freelancing in Sri Lanka}

\author{
Helani Galpaya, Suthaharan Perampalam \\ and Laleema Senanayake
}

\subsection{Introduction: Outsourcing and Micro-work in Sri Lanka}

\subsubsection{Sri Lanka as an Outsourced Work Destination}

Work transformations are being driven by globalization and technological revolution and there is a shift happening from mechanical to digital technology (UNDP 2015, chap. 3). The phenomena of technology changing the boundaries of the firm is not new, and has been documented since the first half of the twentieth century (Coase 1937). The first wave of business process outsourcing took place thanks to the advent of high-speed digital connectivity, which enabled the transfer of vast amounts of data across to locations that had lower cost or other advantages. At first work was transferred from one firm to the same firm's subsidiary located in the cheaper overseas location. Over time, work started being transferred to non-captive firms.

This research was carried out with the aid of a grant from the International Development Research Centre Canada, and the Department for International Development (DFID) UK.

H. Galpaya $(\bowtie) \cdot$ L. Senanayake

LIRNEasia, Colombo, Sri Lanka

S. Perampalam

LIRNEasia, Colombo, Sri Lanka 
Sri Lanka is a lower middle-income country that has benefited significantly from the increase in business process management (BPM) work. Many global BPM operations have set up business in Sri Lanka and provide a range of services to overseas clients, ranging from the low-value added out-bound marketing calls or data entry, to in-and-out bound customer service centers for global banks, to high-value added activities such as medical image processing (reading $\mathrm{x}$-rays), financial account processing and equity research for investment firms. The country has been a desirable location for offshoring for over decade-ranked in the top 10 in Asia (WEF 2015), 14th globally (A.T. Kearney 2016), or 16th globally (Tholons 2016). The BPM sector is projected have strong growth rates for next few years (A.T. Kearney 2015).

Over a decade ago Sri Lanka's private sector and government realized that the country had one of the highest per capita rates of qualified charted accountants in any country. It was also leader in the Human Development Index, indicating readiness in education and health attainment. Therefore, instead of only pursuing the inbound/outbound call center market (which is extremely price sensitive, difficult to attract and retain talent in, and dominated by India and the Philippines), an active push was made toward higher-value work such as accounting, accounts processing. This, combined with improved high-speed Internet connectivity, lower labor costs, implied continued growth in the higher-end of the BPM sector.

The Information technology (IT) industry, (comprising of software services and software product firms) is also booming, with high profile acquisitions of Sri Lankan software firms by global players such as the London Stock Exchange.

Together, the IT-BPM industry has over 300 registered firms (DailyFT 2014), earned over USD 850 million in 2015 (SLASSCOM 2016) and employed over 82,850 people (SLACC 2016). Employment in the sector grew by $17 \%$ between 2003 and 2010 (Department of Census and Statistics 2015a). The sector contributed $0.15 \%$ to the Gross National Product (GNP) in 2016 (Central Bank 2015). ${ }^{1}$

\subsubsection{Online Freelancing/Micro-work Platforms}

The past two decades has seen another type of outsourcing, namely, freelancing and micro-work. Micro-work breaks down large chunks of work into small and simple tasks that rely on human intelligence and distribute these "micro tasks" to workers via Internet for greater cost efficiencies across geographic boundaries (Kuek et al. 2015). Online freelancing refers to slightly 
large chunks of work which are outsourced online, but don't involve crowdsourcing or the automated "assembly" of many micro-tasks to complete the whole (see Hoßfeld 2011 for a typology of online work and differentiating characteristics).

Unlike the traditional BPM industry that uses bilateral contracts between two firms, micro-work outsourced work does not involve long-drawn out/ negotiated bilateral contracts. Often, each job is of extremely low value, enabling the buyer to outsource the work to more than one seller, paying for (i.e. "buying") all jobs that are completed, but only using the best output. The seller of services is usually an individual, and often the buyer is too (as opposed to firms/institutions). Commonly found "jobs" or "gigs" on micro-work platforms include ad-clicking, media tagging, data input, transcribing, data verification, information gathering and summarising, proof-reading, translation, copy editing, graphic design, website design, and website de-bugging.

The above is done online via platforms which allow for end-to-end transactions to be carried out. Starting from market discovery (where the buyers and sellers announce themselves/their work and find each other), contracting (the buyer sources the work from the seller of service, agree on price if applicable), service implementation (the buyer and seller communicate during the carrying out of the work, the seller completes the work) and service/ produce delivery (the seller delivers the out to buyer), payment and post-sale feedback/review of quality. Workers (sellers) advertise themselves by adding a profile on the platform. The profile could include a listing of skills, uploading/links to previous work. Buyers advertise the jobs. Buyers can select the worker directly. The selection may include the buyer examining the sellers previous work and his/her reputational rank on the platform. Alternately, depending on the platform, the buyer can advertise the job and ask sellers to bid for the job, then select one based on lowest price or other criteria. On most websites, the sellers are ranked based on multiple criteria including a satisfaction ranking assigned by past buyers as well as other indicators automatically measured by the platform itself (such as response time to buyers' communications). Payments are done via the platform, which charges a commission (percentage of the value) on what the seller is paid.

The traditional BPM industry requires the provider of services to maintain provide quality assurance through a service level agreement. Micro-work platforms usually don't take on a explicit quality-assurance role. But they do facilitate quality signaling of sellers by allowing buyers to rank sellers based on work done, and allowing sellers to take standardized tests/exams on the platform itself to prove various skills. 
For workers (sellers), online outsourcing has generated new opportunities to access work in a global market, anywhere at anytime, as long as they have a computer, Internet access and the required skills (Kuek et al. 2015).

\subsubsection{Micro-work in Sri Lanka: Is There Potential?}

As Table 14.1 shows, there is awareness of micro-work in Sri Lanka-three specific platforms (Fiverr.com, Freelancer.com, Upwork.com) are popular among web users, and very popular in Sri Lanka relative their popularity in the rest of the world. A relatively high number of workers are registered as potential service providers.

The standard entry-level qualification on recruitment in the IT-BPM this sector was a Bachelors degree, with $63 \%$ of the workforce holding a graduate or post-graduate level qualification (Ph.D., Masters Degree, Bachelor's Degree, Post-Graduate Diploma) in 2013 (ICTA 2013). This means that the employees in IT-BPM sector are the educated-employees include English speaking graduates who have qualified from the highly-selective local universities, branches of overseas universities present in Sri Lanka (attracting those who can afford the fees), universities overseas (which are even more expensive, therefore presenting limited opportunities for the masses), and private technical degree granting institutions which are not classified as universities. Sri Lanka produces around 25,000 university level bachelor's degrees per year, and only 5,778 are computer science and engineering or related topics. They are traditional feeders to the IT-BPM, telecom services and related sector jobs.

Table 14.1 Proxies for the use and popularity of various micro-work platforms in/by Sri Lanka (Source Authors, based on http://www.alexa.com/ and websites of the listed micro-work platforms. The Alexa ranks websites by frequency of access, by country. Registered number of participants is a count of the sellers who self-declare Sri Lanka as their country when registering on each platform)

\begin{tabular}{|c|c|c|c|}
\hline \multirow{2}{*}{$\begin{array}{l}\text { Micro-work } \\
\text { platform }\end{array}$} & \multicolumn{2}{|c|}{ Site rank by Alexa } & \multirow{2}{*}{$\begin{array}{l}\text { Registered number } \\
\text { of Sri Lankans }\end{array}$} \\
\hline & Sri Lanka & World & \\
\hline Upwork.com & 264 & 579 & 5000 \\
\hline Freelancer.com & 289 & 1424 & 5003 \\
\hline Fiverr.com & 67 & 526 & $\begin{array}{l}\text { Fiverr does not allow sorting } \\
\text { registered sellers by coun- } \\
\text { try. But the number likely } \\
\text { to be higher than Upwork/ } \\
\text { Freelancer given the very high } \\
\text { Alexa ranking in the country }\end{array}$ \\
\hline Microworkers.com & $500<$ & 17,905 & - \\
\hline
\end{tabular}


But outside of this, there are persons with skill-sets that are marketable via online platforms-for example, around 1250 men and women complete professional courses that fall short of a bachelor's degree (Gamage and Wijesooriya 2012) Thousands more partially complete diploma courses related to computer literacy, English or graphic design.

Sri Lanka has the highest literacy rate in South Asia, at $92.5 \%$ in 2012 (Central Bank of Sri Lanka 2015). 36.5\% of the total population was able to read and write in English with $23.8 \%$ able to speak it (Department of Census and Statistics 2012). 26.8\% of countries population was computer literate ${ }^{2}$ in year 2015 and over $25 \%$ of households had a computer (Department of Census and Statistics 2015a, b). 19.5\% of the population had Internet access (Central Bank of Sri Lanka 2015). While there is much room for improvement in computer literacy and Internet access, there is broad enough diffusion as to make participation in micro-work as service providers a viable option for many, beyond the elite and educated.

Youth unemployment (at 20\%) is significantly higher than the national unemployment rate (of 4.6\%); female unemployment (at 7.6\%) is also higher than average unemployment (Department of Census and Statistics 2015a). Finding information technology related work for these groups is a possible solution to the unemployment problem.

Therefore, is it possible that the digital dividends could be spread more inclusively (beyond the educated elite) through the participation on micro-work platforms? Is this already happening? If not, why not? And If yes, how do we encourage it?

These are important questions for policy makers in a developing country. We therefore attempted answer the following research questions using a mix of methodologies.

- What is the current incidence of awareness, and participation (i.e. doing work) on micro-work platforms in Sri Lanka?

- What are the skills needed to do the type of jobs commonly available via popular micro-work platforms? What is the availability of such skills in the country?

- What factors make micro-work an attractive (or unattractive) employment option for people with the requisite skills?

- What are the barriers (beyond attitudes) faced by those working on such platforms, or those hoping to work on such platforms? 


\subsection{Methodology}

To answer the above questions, we conducted two separate but connected lines of research using two methodologies. To understand available skill levels in the country, we inserted questions into an ongoing nationally representative sample survey of media use. To understand attitudes toward and experience of micro-work, we conducted a series of focus group discussions. For both, our target age group was the population between the ages of 16-40. The lower level 16 was used is the age when students sit for the Ordinary Level exam (after 10 years of schooling), after which some go into the workforce. Existing literature suggest majority of the online freelance workers are young and between the age group of 18-28 (Kuek et al. 2015). But we wanted to understand the dynamics of such work among slightly older persons who might have the necessary skills to participate on platforms. Therefore our upper age cut-off was set at 40 .

\subsubsection{Quantitative Sample Survey}

Quantitative findings of this paper are based on a nationally representative survey of Sri Lankans aged 16-40. The sample size was 5500 and as designed to represent the target population, covering both urban and rural areas in all provinces and districts of Sri Lanka with $\pm 2.5 \%$ margin of error. The respondents were selected using a multi-stage stratified random sampling method using probability proportional to size (PPS). Fieldwork for the study was conducted in October-December of 2015. The structured questionnaires were designed in English, translated to the local languages (Sinhala and Tamil) and field tested and implemented in the same.

\subsubsection{Qualitative Research Protocols}

The qualitative research was designed to understand perceptions and attitudes towards online micro-work. Six focus group discussions (FGDs) and one in-depth interview (IDI) were carried out in the three population centers: Colombo (4), Jaffna (1) and Galle (1). The discussions were conducted between two separate groups: (a) potential workers (those who have some of the basic skills such as a diploma in computer science, and might be potential candidates for working on online platforms), and, (b) those who are currently engaged in online micro-work. All participants were between the ages of 16-40. Each FGD had between 3 and 6 respondents, and lasted 
$2.5 \mathrm{~h}$ on average. The IDI was with a respondent who could not participate in a FGD, and lasted 2 hours. Of the 30 respondents 18 were male, 12 female; 17 were current micro-workers while 13 had skills but had not done micro-work. Education qualifications of respondents ranged from those with 12 years of education to those with bachelors or equivalent degrees. The protocols were conducted in the two local languages (Sinhala and English) by the authors between February and April 2016, using a semi-structured questionnaire. The conversations were recorded with participants' consent. The recordings were translated to English and transcribed. The authors then analyzed the English transcripts.

Given there is no way to personally identify or contact micro workers through platforms (only their online profile/username is available, not their emails or phone numbers), and given there is no existing listing of such workers to sample from, the research term used a combination of methods to recruit participants for focus groups, including (a) posting a "job" on the platforms, promising payment for workers who fit the screening criteria and agreed to participate in the research, (b) using known persons who worked on such platforms to identify others who did the same (snowballing), (c) using the services of a market research firm to recruit from the field, in return for payment, (d) attending "micro work training programs" provided by third parties in the country, and identifying potential recruits who attend such events.

\subsection{Results and Discussion}

\subsubsection{Low Awareness of and Low Willingness to Do Online Freelancing/Micro-work. Those Willing Are Only Interested in Doing So on a Part-Time Basis}

The national sample survey results show that about quarter of the target population are aware of online freelancing or micro-work. Males are significantly more aware of such opportunities compared to females. The younger and richer the respondent, the higher the awareness. We hypothesized that rural areas may have little awareness of such opportunities, but this turned out not to be the case: $25 \%$ of the rural target population are aware of such opportunities, a number higher than we anticipated, compared $31 \%$ of those in urban areas (Table 14.2). 
Table 14.2 Awareness of and willingness to work online among Sri Lankans aged 15-40 years (Source Authors, based on data from nationally representative sample survey)

\begin{tabular}{|c|c|c|c|c|c|}
\hline & \multicolumn{2}{|c|}{$\begin{array}{l}\text { Awareness on micro-work/ } \\
\text { freelancing }\end{array}$} & \multicolumn{2}{|c|}{$\begin{array}{l}\text { Willingness to work on } \\
\text { micro-work/online free- } \\
\text { lancing jobs }\end{array}$} & \multirow[t]{2}{*}{$\begin{array}{l}\text { Base/all } \\
\text { respondents } \\
N\end{array}$} \\
\hline & $\begin{array}{l}\text { Aware of } \\
\text { online work- } \\
\text { ing opportu- } \\
\text { nities }(\%)\end{array}$ & $\begin{array}{l}\text { Not aware } \\
\text { about online } \\
\text { work oppor- } \\
\text { tunities }(\%)\end{array}$ & $\begin{array}{l}\text { Willing to } \\
\text { do micro- } \\
\text { work }(\%)\end{array}$ & $\begin{array}{l}\text { Not ready } \\
\text { to do } \\
\text { micro-work } \\
(\%)\end{array}$ & \\
\hline $\begin{array}{l}\text { All Sri Lanka } \\
\text { By gender }\end{array}$ & 26 & 74 & 11 & 89 & 5377 \\
\hline Males & 32 & 68 & 14 & 86 & 2227 \\
\hline $\begin{array}{l}\text { Females } \\
\text { By area }\end{array}$ & 21 & 79 & 8 & 92 & 3150 \\
\hline Urban & 31 & 69 & 10 & 90 & 2633 \\
\hline $\begin{array}{l}\text { Rural } \\
\text { By SEC }\end{array}$ & 25 & 75 & 11 & 89 & 2326 \\
\hline SEC $A$ and $B$ & 43 & 57 & 16 & 84 & 1465 \\
\hline SEC C & 27 & 73 & 11 & 89 & 1626 \\
\hline $\begin{array}{l}\text { SEC D and E } \\
\text { By age group }\end{array}$ & 15 & 85 & 8 & 92 & 2025 \\
\hline $16-23$ years & 35 & 65 & 19 & 81 & 1199 \\
\hline 24-31 years & 25 & 76 & 10 & 90 & 1661 \\
\hline $31-40$ years & 19 & 81 & 5 & 95 & 2517 \\
\hline
\end{tabular}

After the initial questions about awareness, the enumerators explained what is meant by micro-work/online-freelancing and gave examples of work available through online platforms. This was followed by questions about whether the respondent is likely to get involved in such work. Only 9\% of the target population responded positively. $12 \%$ of males were more amenable to such work, compared to just over half as much (7\%) for females. Those living in urban areas showed least willingness, possibly reflecting the availability of other employment opportunities. Rural residents were more keen on micro-working/online freelancing. But disproving our hypothesis that only those without access to other job opportunities would be attracted to such work, when we dis-aggregated the data by income, those from the richest households (Socio-economic classification (SEC A and B)) were more willing than those from households with lower SECs. Yet this could also be a reflection of the luxury the rich have in being able to undertake non-permanent, "gig" work, compared to the less affluent respondents who prioritize regular income/salary due to financial constraints. The youngest group was more keen than the older groups to try such work.

We dis-aggregated the "willingness to do micro-work/online-freelancing" by current employment status and skill level of the respondent. Surprisingly, 
the employment status didn't seem to change willingness to do this type of work, with only a small difference seen in the responses of the two groups. But self-assessed skills of the respondent clearly had an impact. We looked at all those with the minimum skills (including basic English, computer typing and data entry) required to do even the lowest-value added work on platforms (such as ad-clicking or entering data). In this group, those that had higher confidence in their skills were more likely to express willingness to do micro-work/online-freelancing once the concept was explained to them (Table 14.3).

Among respondents who are willing do this work, there was a significant preference for doing so as a part time job. This was true among both employed as well as the unemployed. More women were interested in part time work online compared to men (Table 14.4).

The quantitative study revealed the low awareness and low willingness to do online work of this type. Even when people were willing, they were only willing to consider doing so on a part time basis. And to our surprise, willingness wasn't radically different between the employed vs. the unemployed; the only meaningful difference was between men and women. The only "expected" outcome was that people with higher skill levels (among skilled required to do the popular jobs offered on the platforms) being more willing to consider online work.

Why do we see these patterns? Is it that irrespective of employment status, there are such high negative perceptions about micro-work/online freelancing

Table 14.3 Willingness to do micro-work/online-freelancing based on employment status and skills levels of Sri Lankan 15-40 years (Source Authors, based on data from nationally representative sample survey)

\begin{tabular}{|c|c|c|c|}
\hline & \multicolumn{2}{|c|}{$\begin{array}{l}\text { Willingness to work on } \\
\text { micro-work/online freelancing jobs }\end{array}$} & \multirow{2}{*}{$\begin{array}{l}\text { Base (all } \\
\text { respondents) } \\
N\end{array}$} \\
\hline & $\begin{array}{l}\text { Willing to do } \\
\text { micro-work }(\%)\end{array}$ & $\begin{array}{l}\text { Not ready to do } \\
\text { micro-work (\%) }\end{array}$ & \\
\hline All Sri Lanka & 11 & 89 & 5377 \\
\hline \multicolumn{4}{|l|}{ By employment status } \\
\hline Employed & 10 & 90 & 2167 \\
\hline Unemployed & 12 & 88 & 3210 \\
\hline \multicolumn{4}{|l|}{ By skills level } \\
\hline I do not have any skills & 4 & 94 & 3967 \\
\hline $\begin{array}{l}\text { My skills are basic and I } \\
\text { did not get any training }\end{array}$ & 18 & 82 & 685 \\
\hline $\begin{array}{l}\text { My skills are basic and I } \\
\text { got some training }\end{array}$ & 31 & 69 & 556 \\
\hline $\begin{array}{l}\text { My skills are excellent and } \\
\text { I got advance training }\end{array}$ & 53 & 47 & 170 \\
\hline
\end{tabular}


Table 14.4 Preference for full time vs. part-time micro-work/online freelancing (among Sri Lankans 15-40 years who are willing to do such work) (Source Authors, based on data from nationally representative sample survey)

\begin{tabular}{|c|c|c|c|}
\hline & \multicolumn{2}{|c|}{ Nature of commitment } & \multirow{2}{*}{$\begin{array}{l}\text { Base/those who } \\
\text { are willing to do } \\
\text { micro-work } \\
N^{*}\end{array}$} \\
\hline & $\begin{array}{l}\text { Like to do part-time } \\
\text { (Less than } 40 \text { Hrs.) } \\
(\%)\end{array}$ & $\begin{array}{l}\text { Like to do Full time } \\
\text { (More than } 40 \text { Hrs.) } \\
(\%)\end{array}$ & \\
\hline $\begin{array}{l}\text { All Sri Lanka } \\
\text { By gender }\end{array}$ & 77 & 23 & 594 \\
\hline Males & 75 & 25 & 379 \\
\hline $\begin{array}{l}\text { Females } \\
\text { Working statu }\end{array}$ & 82 & 18 & 215 \\
\hline Employed & 75 & 25 & 216 \\
\hline Unemployed & 81 & 19 & 378 \\
\hline
\end{tabular}

that most people won't do it Is it because other "traditional" work is more valued in some way? In our qualitative research (focus groups) we paid particular attention to such questions. Sections below highlight findings from the qualitative research, with specific/direct quotes (from the English transcripts) given where possible.

\subsubsection{Awareness Came Through Multiple Channels}

Online ads (including Facebook ads), blogs, newspaper ads and friends/family were the ways in which first awareness was created.

I got to know about it from a blog post. It had step by step, how everything has to be done. This blog post was done by a Sri Lankan.

One of our lecturers [at the computer training institution] recommended Fiverr as a work platform.

One of my brothers was working in Upwork. I got to know from him.

Several firms also advertised in newspapers that for a fee (of around USD 30 or LKR 5000) they can teach people how to "make money from home" by doing online work. Such firms mostly exposed new workers to online ad-clicking or similar low-value-added work. Some of these training institutions acted as workers on the platforms themselves, hiring newly-trained staff as "subcontractors." 
What they do is, they bring people and train them. They have an account. Odesk or somewhere. They register you as employees of their business. They take work from others and give them. And he submits the work to the buyer. He takes a large amount from the buyer and distributes the employees only a small amounts

\subsubsection{Getting a Foothold on Platforms Is Not Easy, and Signaling Quality Is Important}

Most sites have a rating system for sellers-higher ratings being a strong signaling mechanism for future buyers. Sellers employ various strategies to improve their ranking.

When a job for USD 55 was posted, some people ask if the 55 USD can be divided into 5 USD tasks. That means its 11 tasks. Some people ask whether we can add 11 orders.....From the same person, but he gets 11 reviews... [and goes up in ranking]

Some platforms (for example UpWork and Freelancer) offer exams that the sellers can take. Passing these exams is another signal of quality. Such signals appeared to be particularly important for those who had not done work on the platform before, and had no previous references or ratings.

They [the website] asked me the projects that I've engaged before. I don't have previous experience. There are online exams. When I do these exams the profile becomes 100\% complete and we can work. So I did these work. Then they let me work on the platform.... the exams are free.... If its English, they have English exams. For Word, there are Word exams. You should sit for the exams that you have to work in

These quality signals in turn have a huge impact on how often a seller gets work.

All the hard work is up to the point where you build your profile in freelancing platforms. Once you developed the profile and reach certain level of ranking you can easily make money being at home. Today I am getting got lot of orders from specially from Europeans and Australians. Now I am able to quote more [per job], since I developed a good name and commitment with my clients. With the client base I have co-founded my own venture and it is running successfully.

Getting ranked therefore depends on how many previous jobs one has done, how satisfied the buyers were, how responsive one was on the platform when 
dealing with a buyer and host of other factors. But to get ranked, one has to get on the platform and at least get one job. This first job is the biggest barrier-no one wants to buy services from someone who has never done a job. Successful workers overcome this by "gaming" the system, using their contacts/friends, or by offering to do the (first) job for free. They learn such tactics from their friends who have done the same in the past.

When I put [a profile] up, a customer messaged me. The first job, I did it at a loss...I told him, if he buys a gig, I'll give him another one for free. This was because I wanted to get orders. So, I kept on working with him for a month. After that I kept getting [paid] orders.

I did a trick, asked my friend to purchase several gigs from me and give me good ratings and I paid him back. This is how I built my profile before getting the first job.

Many who never crossed this "first job" barrier never got any work despite registering.

I registered with most of platforms (Fiverr, Freelancer, Upwork), I am maintaining profile each of those platform. I bid for all type of logo designing projects. Competition is very high in online freelance platforms, you are competing with global work force to get the same job.... I still apply for some projects in Fiverr but I am not successful, may be I also have to apply some tricks.

\subsubsection{Flexibility Offered by Freelancing/Micro-work Platforms Is Attractive}

Majority of the current micro-workers we interviewed work on the platforms on a part-time basis, while engaged in other full time jobs, or while studying. They were able to take up the micro-work due to the flexibility.

Most of the time I work at night. When I get an order, I should deliver it within 2 days. So when I get an order, if today is a working day [in my regular job], I go home and finish it today itself. I don't have a specific time per say. I work whenever I can

I go to university and come and do this work during evenings

The choice of different types of jobs on these platforms meant workers can select the jobs that fit their time availability-working intermittently or at a stretch. 
If I do a brochure or leaflet, I can only do one job during this time. The time it consumes is high, it takes about 2,3, hours. But we can do 2, 3 visiting cards within an hour. So, I apply more for these type of small tasks

Respondents also select how much they want to work based on their income needs.

I don't run after this. I earn like 10,000 LKR per month. I try to cover my basic expenses. If I think that I want more money I work or else I will just stay [without working]

\subsubsection{The Range of Work Is Varied. Higher Value Jobs Enable Workers More Control Over Price}

Many with basic computer skills start at the low-value-added end of the spectrum which consists of ad-clicking or entering the data seen on images on screen. These workers have no negotiating power (over price).

Numbers come up in the site, and we have to look at them and click. It shows a number for a certain time. We have to look at the advertisement they stream, and they display a number and tell us to click on that number. When we do that, USD 1 is added [to our account].

[I do] Data entry. They normally send me scanned documents. I look at those things and type.

Social media marketing also repeatedly showed up in the type of jobs many respondents would carry out. Such work gave slightly more opportunities for the worker to make/negotiate price offers.

This guy wanted me to write content and also to publicize one of his tournaments as much as possible to as many people as possible. So I wrote content, and I told him, ok I deliver this to over 25,000 people for this price.

Higher value work was done by those with software development, software testing/debugging skills. These higher value jobs were referred to as "projects."

I liked to work project based. Because I normally do web development. What I do is I fix issues in small business customers. I don't do full projects for 5- 10 USD 
In platforms that matched higher skilled workers with jobs, it was normal for the workers to bid/name their price.

In Elance, Odesk, you go on the platform, look at the project and the scope, and if it can be done we say $O K$ and submit saying this is the cost, this is the proposal and we can deliver at this time. Here, we have control.

[How much I earn per project] depends. As an example, for a small taxi service, think it's a airport drop, people put up a job to create [the website for] an order, pick up venue, time, drop time, etc. So to create this, I quote the project for 400 USD.

\subsubsection{Perceived and Real Barriers Make Micro-work/ Online-Freelancing an Unattractive Full-Time Work Options}

Rarely did we hear from respondents about people quitting their regular/full time jobs and doing online freelancing/micro-work full time. The majority did work on these platforms as a part time activity, in addition to their full time job. Others were students who considered freelancing as a transitory activity.

The security of income of full-time work was attractive to many. Uncertainity of income and uncertainties due to technology challenges were cited as risks of online work. This was the case even when they had consistently earned more through online work compared to their regular/full time job.

Moderator: So if you can get more jobs in Fiverr, will you quit your full time job and work in Fiverr?

Respondent: No I will not. Its because I'm not sure of the situation. Our accounts can be hacked, blocked etc. If something happens, I will loose my income. And there is no permanent income in these work

Workers also said it was more profitable to do some jobs in the local market (face-to face for a local client, on a contract basis) instead of doing the same work online. They also felt that face-to-face customer relationships were stronger than those online.

....more than working on Fiverr, if I make a logo in the local market, I can earn more here than on Fiverr 
The competition [on Fiverr] is high, and there is a temporary bond between the customer and me. If I go to the local market as a freelancer, customers try us. So, the bond we create with the customer is high. So, we can earn more from this work.

Adding to this was the risk of not getting payment from these platforms.

The other risk of Fiverr or whatever, if something happens someday, if an issue arise, say its because Sri Lankan regulations, or because of some other reason, you might loose everything all of a sudden. If that happens, I'll loose my income. In this context, if I had a [traditional] job, with experience, I can go for another job.

For others, the lack of career path in online work made it a purely transitory earning source. For example, content writers did some of the more differentiated types of work. But even they didn't see a future in this work or found the work not challenging.

So, if you want it I think you can have it as a full time thing. For me, it's something on the side. I love writing, but I feel that writing about cookies, cup cakes and trucks it doesn't build up my writing. It doesn't challenge my writing skills.

One of the most significant challenges faced by online workers was the inability to prove their income when attempting to access formal financial services.

There is an issue for Freelancers. When we go to a bank, to get a loan, then ask whether we work in a place where EPF or ETF [government mandated retirement contribution schemes] is deducted. What they truly ask is, from where we receiving money. So, when we say that we are doing an online job, then the bank decides, "Oh, its not a stable job." Then they refuse to give us loans saying that it doesn't comply with their regulations. But this is not an issue in other countries. This is the most pressing issue that Freelancers have

Like most of Sri Lanka, the respondents used pre-paid data bundles for Internet access. Even though entry-level Internet data packages in Sri Lanka are among the lowest in the world, respondents felt they were paying too much for data packages which would reach the capped maximum in a few days. Some were unhappy with data quality, in particular data upload speeds (most ISPs focus on download quality).

Even though the speed is really fast, if the GB level is low, its of no use. It will finish in 2,3 days. 
They [potential buyers] tell us to upload sample videos [before giving a job to create a video]. If we upload these samples, with the data that was used, the amount that we earn will be of no use.

We need uplink [speeds]. Most provide download speed but upload is low. If we host a website, what we need is upload. Its difficult to do it here

As one respondent summarized:

The greatest issue is Internet, next is payment methods, next is electricity, power failures.

Apart from these, cultural attitudes also played a role-lack of acceptance by family and friends discouraged men and women from doing micro-work. Though once earning ability is proven, there seems to be a higher level of acceptance.

They don't understand what I'm doing

... in Sri Lanka there is a culture that has been followed where we have to dress and go outside for a job.

For me of course at the beginning they [parents] kept telling me to do a [proper] job, don't do this type of work, later, when I started performing, they started supporting. People at home was afraid of what will happen because I'm not doing a day job

\subsubsection{Cashing Out Earnings for Work Done Online Is a Problem}

Many respondents (or someone they knew) had done work on certain platforms for an extended period of time, but were unable access the money they had earned. After the failure, many stopped online work altogether.

Then I tried it [ad clicking] out on the computer by my self. I did ad click for several years but I couldn't withdraw money

Some were directed by the micro-work site to open a Paypal to get paid. Sri Lanka doesn't allow Paypal payments. Therefore, even if the micro-work site transferred money to the worker's Paypal account, there was no way to access that money. 
They [the micro-work site] told me to create a Paypal account. Which I did...I asked local banks such as Hatton National Bank and Commercial Bank. What they said is that it cannot be done. The money cannot be withdrawn from Sri Lanka, it can be only done via Singapore. So, then I gave up on the idea of withdrawing that money

Without clear information on how to claim money for work already done when cashing out via Paypal fails, workers blame both the micro-work platform and payment intermediary (which is Paypal in the example below).

That site [the micro-work platform] says that it added USD 1000 to the [my] Paypal account. But when I login to the Paypal account, it doesn't show that money. So, later when I found out, I got to know that, when I create a Paypal account and I add my country as Sri Lanka, what happens is, Paypal itself takes that money. ... That's what people said when I asked around

Some who had friends who had been through this experience before, or had heard about the payment problems in some way, limited themselves to the platforms that offered a clear payment solution. For example, Fiverr was popular because it had recently launched an online debit card.

This [reluctance to use other platforms] is because these sites are linked with Paypal accounts. There is no way in Sri Lanka to convert digital money to physical money... Because Fiverr has a card, we can get physical money.

Specifically, the debit card offered by Fiverr enabled a worker to accrue earnings into the debit card account. Then the worker can go to an ATM machine in Sri lanka to withdraw cash, or use the debit card to make purchases at any location that accepted major credit cards.

They [Fiverr] give the card in partnership with Pioneer. I can load the money to this card. ... I can load the money that I get from Fiverr and cash out from a master ATM located here

This card is not cheap - the card issuer charges USD 3 fee per month and a fee is charged every time the worker draws out cash. Yet this card seemed to be only way to legitimately cash out the earnings. Nearly all current workers we talked to used the Pioneer card.

Other round-about ways existed to cash-outs the money that was earned-for example using a Paypal account that was registered in another country, or creating a Paypal account with a Sri Lankan address and using 
the accumulated money to purchase things online (without cashing out). But most respondents considered this very limiting, and preferred to obtain cash.

... the Paypal account that I use is in Singapore. It was done by a friend of mine who is in Singapore. Its because it cannot be done in Lanka..... [my friend] withdraws money in Singapore and sends to me

A handful of tech savvy respondents had managed to open a "Malaysian" Paypal account from Sri Lanka by faking the IP address of their computer at the time of account opening. This enabled them to transfer money to their bank account in Sri Lanka.

\subsection{Conclusions}

We see from our research that while there are exceptions, for most, microwork/online-freelancing is only a secondary source of income, something to be done in addition to a full time job, while waiting for a full time job or while in education. Traditional cultural preferences for a "office jobs" played a role here-it is less acceptable to say that one is "working from home," especially if one is male. However, once parents/family start seeing high incomes from such work, the negative perceptions appear to lessen. For many, the variable nature of the income was also deterrent, though it was unclear if the variable nature was because they engaged in micro-work part and never really had time to give $100 \%$ to developing a steady source of income online. Inability to prove income when attempting to access formal financial services was also a deterrent because local banks don't have a mechanism for assessing credit worthiness of workers who have variable income, or income from online sources that cannot provide employment references. The inability to get payment for work done due to Paypal not being legal in Sri Lanka was repeatedly cited as a barrier. We talked to workers who had done highly-commoditized jobs (ad-clicking, specifically) for almost a year until they accumulated the minimum amount mandated by platform before cashing-out was allowed. But when they attempted to cash out, they were unable to, because Paypal could not transfer funds to Sri Lanka. The Central Bank of Sri Lanka has been promising for years that this would be done, but changes to policy are yet forthcoming. Even more impactful would be for the banking sector to create account types or credit scoring mechanisms that 
enabled irregular income earners, self-employed workers, or informal sector workers to have access to formal financial services.

General lack of awareness (with less than $25 \%$ of the target population knowing what micro-work or online freelancing is) is a problem to expanding this market - without knowing of opportunities, few will look for them. More importantly, few will acquire the skills needed for online platforms. Everyone who gets the basic computer skills will expect to obtain jobs in the highly competitive software industry, or abandon those skills and find other employment, instead of realizing there is an intermediate market which values their skills.

The worker's level of skill is one of the biggest determinants of how much one earns. The highly commoditized end of the spectrum (ad-clicking) earns little income. The workers are price-takers and have no ability to differentiate themselves. In the middle of the spectrum, jobs such as logo design require more skill, but are still sold at platform-specified prices, is being commoditized and facing severe price competition due the entry of low cost workers from India, Pakistan etc. The higher-end of the market involves developing software/web functionality. Here, the workers are often able to negotiate a price with their buyer-if not on the first job, certainly in subsequent jobs. This type of work also often leads to repeated engagement between buyer and seller (with most taking the work off- platform and building a direct relationship). It is here that Sri Lanka needs to target-and promote this type of online work as a viable full-time or part-time option for those who cannot get employment in Sri Lanka's world-famous software firms, but still posses basic coding skills. This end of the spectrum is not necessarily safe from competition either, and is being undercut on price by Indian and Pakistani workers, but because of the longer term relationships, enables the sellers more control over time, price, and quality.

We see success-stories of workers earning significant income each month through online-free lancing and micro-work. We have even observed many who start at the low-value-added end (ad-clicking) or logo design, and move onto higher value jobs such as web-site design. The common factor in those who made this "migration" was peer learning. How to get paid on a platform, how to get the first job, how to get a higher ranking: these were all "tricks of the trade" that most learned from their network of peers who had done it before. Many who dropped off or never migrated to higher value platforms did so because they never learned these strategies. It is possible that more online or offline "meetups" and networking events can be organized to help develop peer networks for current and potential workers. 
Such networks will help overcome real barriers as well as perceived barriers (which keep potential workers from getting online and seeking work).

Despite specific attempts to recruit females who were stay-at-home mothers and were also current micro-workers, we only found one respondent in our research (other women we interviewed were students or had other employment). This is at least some indication that there is a huge untapped marketwomen's participation in the labor force can be significantly improved (from the current low figure of 26\%) through online platforms. By enabling women to work from home, those with young children will be able to achieve some work-life balance without stepping off the workforce all together.

Whether people engage in it as full time or part time work, online work presents a way to increase their income, sometimes significantly. Sufficient number of people with the right type of skills exist in the country. However, it has to be "pitched" right-awareness has to be increased, but only along with the pitfalls (e.g., not getting paid for work done), and solutions to these pitfalls. This can be done by private sector providers, specially private sector players well beyond the ones who are currently promoting these opportunities (primarily the educational institutions who offer 3-6 month computer training courses, or the training institutions that teach people how to make money online as their business model). For example, for telecom operators, micro-workers can be a high-revenue market segment since Internet data needs of such workers are higher than the average consumer's and possibly more different (need for higher uploading speeds, instead of download only). These firms (or the workers themselves) can facilitate peer networking which help build the soft skills which help to move workers up the value chain, away from commoditized work on platforms.

We conclude that online freelancing and micro-work presents a growth opportunity for Sri Lanka.

\section{Notes}

1. Calculated by the authors based on Central Bank data, 2015 (IT Programming Consultancy and Related Activities: 16,409, Total Gross National Income at Market Price: 10,931,932).

2. Definition for Computer literacy: A person (aged 5-69) is considered as a computer literate person if he/she could use computer on his/her own. For example, even if a 5 years old child can play a computer game then he/she is considered as a computer literate person. 


\section{References}

A.T. Kearney. 2015. Emerging Markets_Where the Money Is for Australian Companies. https:/www.atkearney.com.au/documents/8942229/8942900/Emerging+Markets_ Media+Release_Approved_.pdf/d87adc33-d637-4ddd-bd22-f38862b7326c.

A.T. Kearney. 2016. A.T. Kearney Releases 2016 Global Services Location Index (GSLI). http://www.atkearney.co.uk/news-media/news-releases/-/asset_publisher/ 00OIL7Jc67KL/content/id/7170816.

Central Bank of Sri Lanka. 2015. Annual Report 2015. Colombo: Central Bank of Sri Lanka. http://www.cbsl.gov.lk/pics_n_docs/10_pub/_docs/efr/annual_ report/AR2015/English/17_Appendix.pdf.

Coase, Ronald. 1937. "The Nature of the Firm." Jstor.Org. http://www.jstor.org/ stable/2626876.

DailyFT. 2014. "ICT Workforce Rises by 50\% Since 2010, National ICT Workforce Survey 2013 Reveals." http://www.ft.lk/article/287932/ICT-workforce-rises-by-50_ since-2010-National-ICT-Workforce-Survey-2013-reveals.

Department of Census and Statistics. 2012. Census of Population and Housing 2012. Colombo: Central bank of Sri Lanka. http://www.statistics.gov.lk/PopHouSat/ CPH2011/Pages/Activities/Reports/CPH_2012_5Per_Rpt.pdf.

Department of Census and Statistics. 2015a. Statistical Pocket Book 2015. Colombo: Department of Census and Statistics. http://www.statistics.gov.lk/ pocket $\% 20$ book/chap13.pdf.

Department of Census and Statistics. 2015b. Computer Literacy Statistics-2015 (First Six Months). Colombo: Department of census and statistics. http://www. statistics.gov.lk/samplesurvey/ComputerLiteracy-2015Q1-Q2-final\%20.pdf.

Gamage, Sujata, and Tilan Wijesooriya. 2012. "Mapping the Higher Education Landscape in Sri Lanka." Presentation, LIRNEasia.

Hoßfeld, Tobias, Matthias Hirth, and Phuoc Tran-Gia. 2011. "Modeling of Crowdsourcing Platforms and Granularity of Work Organization in Future Internet." In International Teletraffic Congress (ITC). IEEE. http://ieeexplore. ieee.org/document/6038475/.

Kuek, Siou Chew, Paradi-Guilford, Cecilia Maria, Toks Fayomi, Saori Imaizumi, and Panos Ipeirotis. 2015. The Global Opportunity in Online Outsourcing. Washington, DC: World Bank Group. http://documents.worldbank.org/curated/ en/138371468000900555/pdf/ACS14228-ESW-white-cover-P149016Box391478B-PUBLIC-World-Bank-Global-OO-Study-WB-Rpt-FinalS.pdf.

Sri Lanka and Australia Chamber of Commerce (SLACC). 2016. "What Makes Sri Lanka the No.1 Destination for IT-BPM Services?” Presentation.

Sunday Observer. 2016. "IT-BPM Industry Poised for Growth-SLASSCOM." http://archives.sundayobserver.lk/2016/05/08/fin02.asp.

Tholons. 2016. Tholons 2016 Top 100 Outsourcing Destinations. Tholons. http:// www.tholons.com/TholonsTop100/pdf/Tholons_Top_100_2016_Executive_ Summary_and_Rankings.pdf. 
United Nations Development Program. 2015. Human Development Report 2015Work for Human Development. Washington, DC: United Nations Development Programme. http://www.hdr.undp.org/sites/default/files/2015_human_development_report.pdf.

World Economic Forum. 2015. "Global Information Technology Report 2015.” World Economic Forum. http://reports.weforum.org/global-information-technologyreport-2015/economies/\#indexId=NRI\&economy=LKA.

Open Access This chapter is licensed under the terms of the Creative Commons Attribution 4.0 International License (http://creativecommons.org/licenses/ by/4.0/), which permits use, sharing, adaptation, distribution and reproduction in any medium or format, as long as you give appropriate credit to the original author(s) and the source, provide a link to the Creative Commons license and indicate if changes were made.

The images or other third party material in this chapter are included in the chapter's Creative Commons license, unless indicated otherwise in a credit line to the material. If material is not included in the chapter's Creative Commons license and your intended use is not permitted by statutory regulation or exceeds the permitted use, you will need to obtain permission directly from the copyright holder. 